\title{
EXPERIMENTS RELATING TO THE FRACTURE OF BEDROCK AT THE ICE-ROCK INTERFACE
}

\author{
By JenNifer M. Smith* \\ (Department of Geography, University of Aberdeen, St. Mary's, High Street, Old Aberdeen AB9 2UF, U.K.)
}

\begin{abstract}
MacClintock (1953) has suggested that arcuate features formed on glass by the impression of steel ball bearings may be analogous to crescentic gouges observed on formerly glaciated rock surfaces. He noted that cracks, convex in the direction of movement, are formed as bearings roll over a glass surface but not as they slide over it. MacClintock therefore proposed that the similarly orientated crescentic gouges may owe their origin to abrading clasts rolling along a glacier bed. This note describes simple experiments designed to test this view by generating friction cracks artificially. Cracks convex and concave in the direction of movement were produced by a non-rolling bearing - a result apparently incompatible with MacClintock's proposal. It is suggested that the orientation of such cracks is less dependent on bearing rotation and more the result of pressure variation. Cracks analogous to crescentic gouges may form as a result of unloading.
\end{abstract}

RÉsumé. Expériences relatives à la fracture du lit rocheux à l'interface glace-rocher. MacClintock (1953) a suggéré que les fêlures en arcs produites par la trace d'une bille d'acier sur du verre pourraient être analogues aux coups de gouge en croissant observées sur les surfaces rocheuses autrefois englacées. Il notait que ces fêlures, convexes dans la direction du mouvement se forment lorsque la charge roule sur une surface de verre mais non lorsqu'elle glisse sur cette surface. MacClintock a donc proposé que les coups de gouges en croissants orientés de même manière peuvent devoir leur origine à des sédiments abrasifs roulant sur un lit rocheux. Cette note décrit des expériences simples destinées à contrôler cette hypothèse en provoquant

\section{INTRODUCTION}

In a short note, MacClintock (1953) reported the results of an experiment by Preston (1921) in which optical glass was artificially scored by rolling and non-rolling steel ball bearings. It was suggested by Preston that cracks formed by non-rolling bearings are concave in the direction of movement and those formed by rolling bearings are convex in the direction of movement. MacClintock's claim that the results of Preston's experiment may offer an explanation for crescentic gouges has subsequently been accepted and quoted by others without further experimentation, for example Embleton and King (1975) and Thorp (1981). Simple experiments were devised to test the hypothesis that the orientation of artificially generated friction cracks depends on whether or not the abrading clast is rotating.

\section{EXPERIMENTAL PROCEDURE AND RESULTS}

Attempts to replicate Preston's experiment were hindered by the incomplete experimental description in the original publication (Preston, 1921). In the experiments reported here, a $5 \mathrm{~mm}$ diameter steel ball bearing was forced down upon glass approximately $2 \mathrm{~mm}$ thick using a clamp (Fig. 1). Pressure with a low angle of obliquity was achieved by using a swivelheaded clamp. Its fixed nature, however, necessitated the introduction of lateral movement by one of three methods: impacting the edge of the glass sheet, impacting the clamp, or pulling the clamp over the sur-

*Present address: Map Research and Library Group, Mapping and Charting Establishment, Government Buildings, Hook Rise South, Tolworth, Surbiton, Surrey, England artificiellement des fissures de friction. Des fissures convexes et concaves dans la direction du mouvement ont été produites par une charge non roulante - un résultat évidemment incompatible avec les propositions de MacClintock. On suggère que l'orientation de ces fissures dépendent moins de la rotation de la charge que de la variation de la pression. Des fissures analogues aux coup de gouge en croissants peuvent se former comme résultat du déchargement.

Zusammenfassung. Versuche zum Ausbruch von Fels an der Berührungsfäche zwischen Eis und Fels. MacClintock (1953) hat vermutet, dass bogenformige Erscheinungen, die sich auf Glas durch den Eindruck von Kuellagern bilden, ein Analogon zu sichelartigen Eintiefungen sein könnten, die auf früher eisbedeckten Felsflächen zu beobachten sind. Er bemerkte, dass Sprünge, die in Bewegungsrichtung konvex verlaufen, entstehen, wenn die Lager über die Glasfläche rollen, nicht aber, wenn sie darüber gleiten. MacClintock nahm daher an, dass die ähnlich orientierten Sichelbrüche auf Felsbrocken zurückzuführen seien, die über ein Gletscherbett rollen. Diese Arbeit beschreibt einfache Versuche zur Stützung dieser Ansicht durch künstliche Erzeugung von Reibungssprüngen. Sprünge, sowohl konvex wie konkav in Bewegungsrichtung, wurden durch ein nicht-rollendes Lager erzeugt, - ein Ergebnis, das MacClintocks Annahme widerspricht. Es wird vermutet, dass die Orientierung solcher Sprünge weniger von der Rotation des Lagers abhängt, hingegen eher das Ergebnis von Druckänderungen ist. Sprünge, analog zu Sichelbrüchen, dürften entstehen, wenn der Druck ausgeladet ist.

face. With this experimental procedure it was difficult to tell whether the bearing was rolling or not, except at low pressures when rolling was observed. However, the bearing could be prevented from rolling by securing it to the hard rubber pad of the clamp with a strong glue. After carrying out the experiments the bearing was still securely attached to the clamp. The traces of cracks made by the ball bearing on the glass were then examined under a microscope. An obvious limitation of the experimental procedure was that the pressures on the bearing could not be measured. However, even the relative differences reported here yield significant results and it is hoped that they may be helpful for anyone designing future, more sophisticated experiments.

Typical traces made by a bearing which was definitely not rolling are shown in Figures 2 to 4 . Figure 2 shows a trace obtained using relatively low pressure. The cracks are concave forward and appear analogous to traces observed in Preston's experiments which involved abrading with a non-rolling bearing. The smaller cracks which flank the main trace on

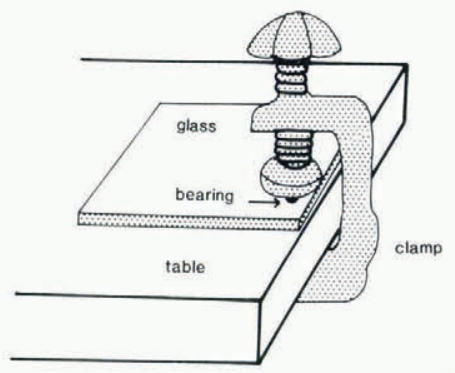

Fig.1. Experimental design. 


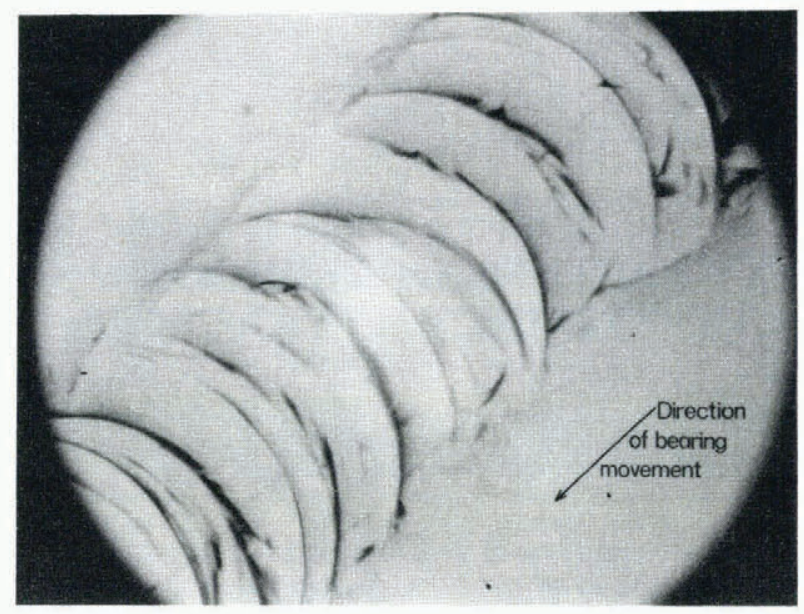

Fig.2. Trace made by non-rolling bearing under relatively low pressure showing concave-forward cracks (x 50 magnification).

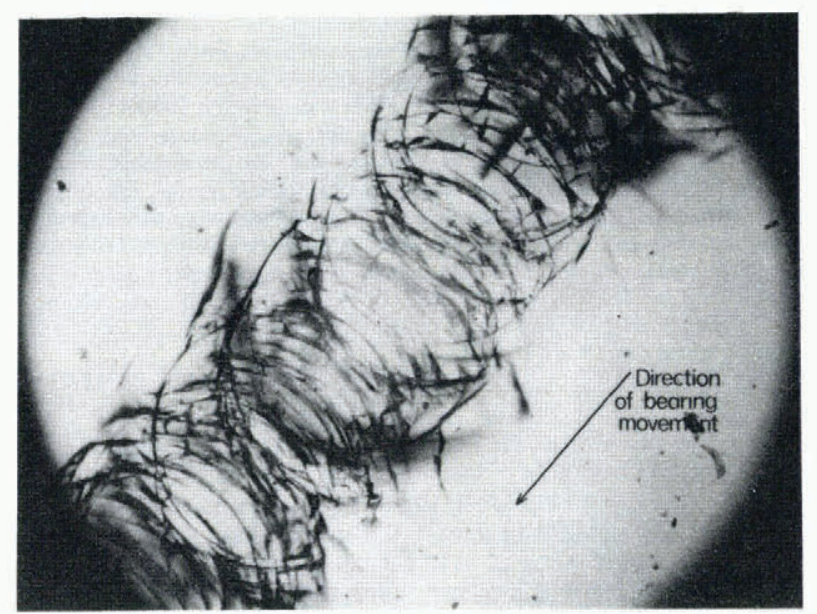

Fig.3. Trace made by non-rolling bearing under relatively high pressure (×25 magnification).

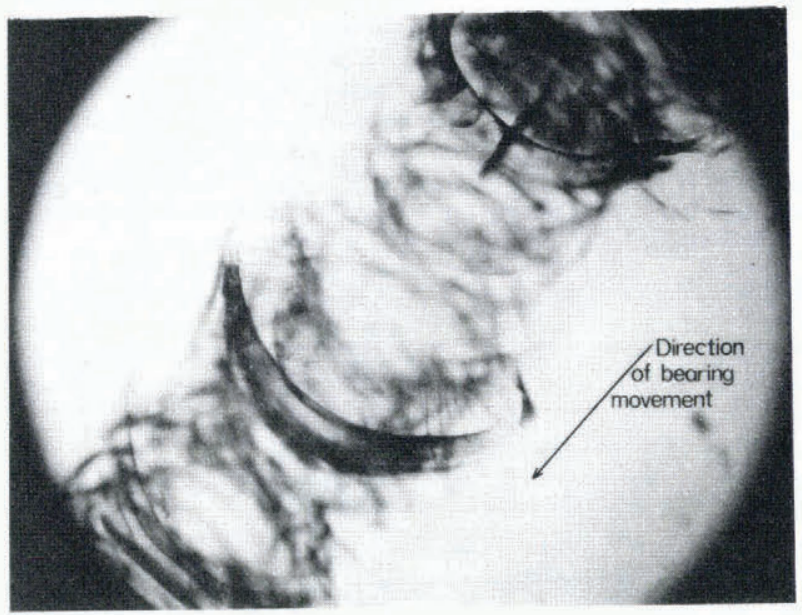

Fig.4. As Figure 3 but with focus altered to show convex-forward cracks more clearly.
Figure 2 are probably what Preston described as lateral flaws.

When pressure is increased a trace similar to that shown in Figure 3 is typical. In this case, concaveforward cracks similar to those in Figure 2 are more closely spaced and, at periodic intervals, cracks of a "reversed" orientation are visible. Some of these are similar in shape and size to the concave-forward cracks, and by observing ten traces, of which Figure 3 is representative, it is suspected that these are circular, ring cracks caused by the pressure of the bearing on the glass (Lawn and Wilshaw (1975)). However, at intervals along the trace larger, "reversed" cracks are visible. By adjusting the microscope to focus on increasingly lower planes within the glass, these larger cracks are seen to be deep phenomena which slope downwards in the direction of movement as shown on Figure 4. Similar, deep-seated cracks have been observed experimentally in ice beneath indenters when the load is removed (Goodman and Tabor, 1978). These authors suggest that in such a situation the sub-surface tension component about the deformed zone beneath the indentation nucleates and propagates another set of laterally extending cracks. Such cracks are related to unloading following the release of high contact pressure.

\section{CONCLUSIONS}

Three main conclusions are drawn from these experiments.

(1) The convex-forward cracks described by Preston as being formed by rolling bearings may also be obtained by pressing non-rolling bearings on glass. (2) Concave-forward cracks occur at a variety of pressures but deep convex-forward cracks form only under relatively high pressures.

(3) The production of deep convex-forward cracks is thus more dependent on pressure than on bearing rotation.

\section{POSSIBLE SIGNIFICANCE FOR GLACIAL EROSION}

The shallow, concave-forward cracks produced in the experiments are thought to be analogous to crescentic fractures observed in some areas of glacial erosion. As described by Lahee (1912) and Harris (1943), crescentic fractures are superficial, hyperbolic cracks with only one steeply dipping fracture and no material removed. It can be suggested that they are formed as bedrock fails under tension behind a moving clast.

The larger, convex-forward cracks are analogous to crescentic gouges. As described by Chamberlin (1888, p.218-24), Gilbert (1906), and Harris (1943), crescentic gouges are larger than crescentic fractures and are composed of two fractures; a gently sloping one and a steeper one. From the glass experiments these can be inferred to reflect lateral cracks and ring cracks respectively. It can be suggested that, as with the glass experiments, crescentic gouges are formed as bedrock fails following the passage of clasts under high contact pressures.

\section{ACKNOWLEDGEMENTS}

These experiments were carried out while I was an undergraduate at Aberdeen University. I would like to thank Dr D.E. Sugden and Dr A.M.D. Gemmell for their encouragement.

\section{REFERENCES}

Chamberlin, T.C. 1888. The rock-scorings of the great ice invasions. U.S. Geological Sumey. 7th Annual Report, [for the year] 1885-86, p. 147-248.

Embleton, C., and King, C.A.M. 1975. Glacial geomorphology. [Glacial and periglacial geomorphology. second edition. Vol.1.] London, Edward Arnold. 
Gilbert, G.K. 1906. Crescentic gouges on glaciated surfaces. Bulletin of the Geological society of America, Vol. 17, p. 303-16.

Goodman, D.J. and Tabor, D. 1978. Fracture toughness of ice: a preliminary account of some new experiments. Jourmal of Glaciology, Vol. 21, No. 85, p. 651-60.

Harris, S.E. 1943. Friction cracks and the direction of glacial movement. Joumal of Geology, Vol. 51, No. 4 , p. 244-58.

Lahee, F.H. 1912. Crescentic fractures of glacial origin. American Joumal of Science, Fourth Series, Vol. 33, No. 193, p. 41-44.
Lawn, B.R., and Wilshaw, T.R. 1975. Fracture of brittle solids. Cambridge. Cambridge University Press.

MacClintock, P. 1953. Crescentic crack, crescentic gouge, friction crack, and glacier movement. Jourmal of Geology, Vol. 61, No. 2, p. 186.

Preston, F.W. 1921. The structure of abrading glass surfaces. Transactions of the optical Society, Vol. 23, No. 3, p. 141-46.

Thorp, P.W. 1981. An analysis of the spatial variability of glacial striae and friction cracks in part of the western Grampians of Scotland. Quatermary Studies (City of London Polytechnic - Polytechnic of North London), Vol. 1, p. 71-94.

MS. received 10 December 1982 and in revised form 6 December 1983 